\title{
Business groups and transnational capitalism in Central America:
}

\section{Economic and political strategies}

Benedicte Bull, Fulvio Castellacci and Yuri Kasahara

Chapter 1: Introduction: the emergence and evolution of business groups in Central America 
Table of contents

List of abbreviations

1. Introduction: the emergence and evolution of business groups in Central America

2. Between hierarchies and networks: understanding business group strategies in a global capitalism

3. Regional shifts and national trajectories: differences in the context and strategies of business groups

4. From oligarchs to transnational business group leaders? The shifting strategies of key business groups

5. Internationalization and the Export Performance of the Central American business groups

6. Central American Business Groups, Innovation and Institutional Conditions

7. The role of the state: governmental financial policies and business group strategies

8. Between the back and the front stage - the political strategies of Central American business groups

9. Conclusion

References 
List of abbreviations

\begin{tabular}{|l|l|}
\hline ALBA & The Bolivarian Alliance for the Peoples of our America \\
\hline ANDI & National Industrial Association \\
\hline ANEP & National Association of Private Business \\
\hline ARENA & Bational Republican Alliance \\
\hline BANAMER & Nicaraguan Bank of Industry and Commerce \\
\hline BANCENTRO & Agriculture Export Bank \\
\hline BANEX & Honduran Savings Bank Group \\
\hline BGA & Central American Common Market \\
\hline CACM & Central American and Dominican Republic Free Trade Agreement \\
\hline CAFTA-DR & Chamber of Commerce, Industry, and Agriculture of Panama \\
\hline CCIAP & Democratic Change \\
\hline CD & Coordinated Market Economies \\
\hline CME & Colón Free Trade Zone \\
\hline CFTZ & National Center for Registries \\
\hline CNR & National Executive Council of Arena \\
\hline COENA & National Investment Corporation \\
\hline CONADI & Superior Council of the Private Enterprise \\
\hline COSEP & Foreign Direct Investment \\
\hline DBG & Industrial and Agricultural Financial company \\
\hline EGI & FDIsiness group \\
\hline
\end{tabular}




\begin{tabular}{|l|l|}
\hline GAF & Group Affiliated Firm \\
\hline GANA & Grand Alliance for National Unity \\
\hline GDP & Gross Domestic Product \\
\hline GEFG & American General Electric Finance Group \\
\hline HME & Hierarchical Market Economies \\
\hline LAFISE & Freedom and Refounding party \\
\hline LIBRE & Liberal Market Economies \\
\hline LME & Libertarian Movement \\
\hline ML & Multinational Corporation \\
\hline MNC & Panamenista Party \\
\hline PA & Citizens Action Party \\
\hline PAC & National Progress Party \\
\hline PAN & Constitutionalist Liberal Party \\
\hline PLC & Liberal Party of Honduras \\
\hline PLH & National Liberation Party \\
\hline PLN & National Party of Honduras \\
\hline PNH & Democratic Revolutionary Party \\
\hline PRD & Social Christian Unity Party \\
\hline PUD & Research and Development \\
\hline PUSC $\& D$ & Stand-alone Firm \\
\hline
\end{tabular}




\begin{tabular}{|l|l|}
\hline USAID & United States Agency for International Development \\
\hline VoC & Varieties of Capitalism \\
\hline
\end{tabular}




\section{Chapter 1: Introduction: the emergence and evolution of business groups in Central}

\section{America}

\subsection{Introduction}

Central America as a region has made world headlines mainly due to civil wars, insurgencies and more recently drug-trafficking and violent youth gangs. Central American enterprises are only rarely studied, and even less so, the Central American conglomerates and business groups, that albeit small by Latin American and global standards play a significant role in the region's economies. If they are studied at all, it is mainly as supporters of repressive dictatorships or corrupt regimes, or as the incarnation of colonizers and landholders, dominating the system that is considered to be the root causes of most of Central American problems. They are assumed to have the power to dominate politics and the state and, as a parallel power structure, be able to perpetuate themselves in power in a way that no democratically elected politicians have ever been able to do.

However, these accounts often overlook the significant differences between the different business groups. And more importantly, they fail to recognize the profound changes that they are going through as they are adapting to new international economic realities. The purpose of this book is to contribute to a more profound understanding of the transformations of these groups. This is not only viewed as important for academic purposes. As these groups have historically played a key role in the development of the region, we consider it also to be of high importance for the future of the regional development.

In a global context, business groups and particularly diversified business groups (DBGs) that sprawl across multiple apparently unrelated sectors are a well-known and studied phenomenon. A large body of literature intends to answer the questions of why they 
predominate in certain contexts, how they fare in increasingly transnational economies and what impact they have on development. However, this literature has largely focused on Asian and European economies and to the extent they have included Latin American groups, the focus is on the groups from the large economies of the region: Brazil, Mexico and Argentina, and to some extent Colombia, Chile and Peru (Peres 1998, Schneider 2013). Only Segovia's 2005 study of the regional groups provides a systematic analysis of Central American groups, but focuses exclusively on the groups that successfully have internationalized their activities (Segovia 2005). Also the increasing literature on the Latin American multinational companies, the so called multilatinas (Cuervo-Cazauro 2011, Casanova 2009, 2012) has generally overlooked Central America. Nevertheless, both bodies of literature provide important insight that this book has drawn on.

Devoid of concrete information about them, the Central American diversified business groups and their leaders have acquired almost mythological dimensions in the local public discourse. Figures such as Dionisio Gutierrez in Guatemala, Stanley Motta in Panama, Ricardo Poma in El Salvador, Carlos Pellas in Nicaragua and Miguel Facussé in Honduras are treated in the public debate with a mix of admiration, contempt and fear. They are admired for being successful businessmen and purveying a sense of modern management in the midst of economies dominated by informal relations; they are despised as they concentrate immense fortunes in countries with high levels of poverty; and they are feared because of their influence in political and security circles. Yet, as few of the companies they own and manage are public, the information available about them is scarce. They do not willingly share information about turnover, profits, employees or investments, and apart from in the case of financial companies, they are under no obligation to do so. 
This is of course not only a problem for the public debate; it has also been a major challenge for us. We have tried to resolve the lack of reliable data by cross checking a number of semireliable sources and arriving at information about the companies that we feel relatively confident give a correct picture. When exhausting public registries, we have read business magazines, newspapers and biographies, and conducted interviews. The disciplinary approach is a mix of political science, sociology, international political economy and economics, reflecting the multidisciplinary background of the research team.

The main purpose of this is not only to generate knowledge about the business groups, but to understand the rationale for the strategies they apply to confront the rapid transformations of the economies in which they are embedded, and what can explain it in the cases that have had major success. Through arriving at a better understanding of this, we also aim to better understand the dynamics of growth and development in Central America generally, and how business group strategies contribute to that in the different countries.

While we started out studying the changes in business group strategies as a result of major changes in the global political economy and the policy shifts in Central America that increasingly opened the region, one of our first findings was that the strategies of the business groups differ greatly across the six tiny countries of the isthmus: Guatemala, Honduras, El Salvador, Nicaragua, Costa Rica and Panama. Thus, we have been concerned to include a focus not only on international economic drivers, but on formal and informal domestic institutions and how these condition, but are also conditioned by, the actions and strategies of the main business groups.

Our study builds on institutional literature in the varieties of capitalism tradition. A main inspiration is the work of Ben Ross Schneider on the Latin American form of hierarchical capitalism $(2008,2010,2013)$, that view DBGs as an integrated element in a form of 
capitalism that is characterized by negative complementarities between the organization of business into sprawling, diversified groups, strong presence by multinational companies (MNCs), atomistic labor relations and low investments in skills and technology. The result is continued low productivity growth and thus, sustained structural inequality and long term low growth.

However, Central America also presents some particular characteristics that are not well accounted for in this literature. First, as our study of Central American DBGs reveal, although many have a hierarchical structure, they are highly interlinked between each other in a way that makes in necessary to study networks between them as well as hierarchical relations coordinating the companies within them. Second, close integration of the business groups across the region in spite of much dissimilarity in national institutional contexts, presents a challenge to the VOC literature that is frequently criticized for being too nationally focused (Nölke and Vliegenhart 2009). Third, in spite of recent attempts to include a political dimension in the analysis of DBGs (e.g. Schneider and Soskice 2009), the VoC literature still falls short of accounting for the intimate relationship between economic and political elites in the small Central American countries and how that conditions private sector strategies. Fourth, the frequent critique against the static nature of the VoC approach becomes even more problematic in the small, open Central American countries that are highly vulnerable to changes in the international economic context. These are issues that will be addressed throughout this book.

Although we situate this study in an international literature, the emergence of the evolution of the DBGs in Central America is also highly conditioned on the region's economic history. Thus, in the following, we will first discuss the defining characteristics of business groups, before we give a brief historical account of the emergence and evolution of the currently 
dominating business groups in Central America and the economic performance of the region. Subsequently we will outline the main arguments of this book and sketch out the remaining chapters.

\subsection{Defining characteristics and varieties of business groups}

There is little agreement in the literature about how to define the sprawling networks of companies, mutual share-holderships, families and political interest-groups dominating the political economy of several Central American countries. In most of the literature specific to the region these have been conceptualized through concepts that somehow attempt to capture simultaneously their economic resources and their influence on political decisions. Some take an explicit or implicit structural or Marxist point of departure and talk about ruling classes (Stone 1990), dominant classes (Mahoney 2001) or elites, encompassing landholders, as well as the industrial bourgeoisie (Rueschemeyer, Stephens and Stephens 1992; Flora and TorresRivas 1989; Paige 1997). Their economic strength as well as political influence are viewed as derived from the ownership of assets (land, capital), and splits within the dominant classes are understood as a result of the differences in the interests derived from different forms of capitalist production: agriculture, industry, commerce and finance.

More recent studies have used concepts such as 'hegemonic bloc' (Paniagua 2001), power groups (Segovia 2005), or elites (Dosal 2005, Palencia Prado 2002, Váldes 2003) in order to capture the simultaneous economic and political clout of big business. We have taken a different approach; our starting point is the more specific figure of the business group typically defined as 'legally independent firms, operating in multiple (often unrelated) industries, which are bound together by persistent formal (e.g. equity) and informal (e.g. family) ties' (Khanna and Yafeh 2007, p. 331). We have chosen this as our main focus of as 
we have needed a more precise definition than the ones referred to above in order to make a multi-sectoral comparison across national contexts, such as intended here.

However, the concept of business group also encompasses a number of variations. Business groups differ, regarding the kind of ties that bind the different enterprises within the group together, their internal ownership structure, and their degree of diversification. The linkages that bind the business groups together may include mutual share-holdership, close market ties (such as inter-firm transactions), and/or social relations (family, kinship or personal friendship ties) through which they coordinate to achieve mutual objectives. Regarding ownershipstructure, some might be of the network type, defined as a constellation of legally independent companies that cooperate for common, long-term goals, whereas others are hierarchies in which a holding company owns and controls legally independent operating units, usually organized as subsidiaries and affiliates. Within the latter group one may further distinguish between multicompany firms which transact in different markets but which does so under common entrepreneurial and financial control, and pyramidal business groups that allow owners to tunnel profits from second and third tier subsidiaries to owners (Colpan and Hikino 2011)).

Another difference is whether the group is presented as a group. Rettberg argues for example that business groups are 'networks of legally independent firms, affiliated with one another through mutual shareholding or by direct family ownership under a common group name' (Rettberg 2005). However, in Central America, we find a number of constellations of networks of companies with mutual shareholdership that do not appear under a common name, but that are nevertheless bound together by persistent relations. Moreover, often time we find formal groups with owners that also own a number of companies that are not formally in the group but that are financially and administratively coordinated with the rest. This complicates 
significantly the identification of groups since one needs a lot of knowledge about the relations between the different companies in order to conclude about whether they belong to the same group.

Our strategy to diminish, if not overcome, this problem has been to focus on the family owned groups. These are the overwhelmingly dominant ones in Central America, and starting with the family or family network has helped us to identify the business groups. Our definition of a diversified business group is thus: a set of legally independent firms, operating in multiple (often unrelated) industries, which are controlled by a family or family network through direct ownership, mutual shareholder ship, or other forms of persistent linkages.

This does not mean that families necessarily own the companies exclusively. As pointed out by Khanna and Yafeh (2007, p. 331), varying degrees of participation of outside investors characterize many business groups around the world, also the family owned. In Central America, the degree of shareholding between different business groups is also widespread and it can sometimes be difficult to decide where one group ends and the other starts. Nevertheless, for our purposes, we start with the business groups, and secondly, intend to unravel the networks and connections between the different groups.

\subsection{From landowners to CEOs of diversified business groups: the evolution of Central American economic elites}

\subsubsection{The emergence of business groups in Central America}

The development of the Central American business groups reflects in many ways the economic evolution of the region, and thus also the major differences between the different Central American countries. Throughout this history, while there are clear aspects of 
continuity - of the same families or family networks dominating the economy through adapting to new economic realities - we also see new actors and elites emerging with the rise of new economic sectors, political upheavals or flows of migration.

Some of the currently existing business groups can date their roots back to the control that their families have exerted over land and politics since colonial times. This is true for example of the Castillo family of Guatemala, that proudly refer to their direct descent from the conquistador Bernal Díaz del Castillo (Dosal 2005, p.30), and that has evolved into a dominating industrial family currently heading two of the dominating Guatemalan groups (Cabcorp and Hermanos Castillo). The colonial elite produced and exported cattle, gold, silver and in El Salvador and Guatemala, cochineal and indigo dye. However, it was with the liberal reforms of the 1870s and the parallel establishment of the agro-export economy that the economic elite in Central America was consolidated. By the late 19th century, coffee had acquired a dominating position in export earnings in all the countries in the isthmus except Honduras: It accounted for $96 \%$ of export earnings from Guatemala (1989), 91\% from Costa Rica (1890), 71\% from Nicaragua (1890) and 66\% from El Salvador (1982). Among the current business groups that can trace their roots back to the late 19th century coffee-boom, we find for example the Regalado Dueñas in El Salvador. This family controlled not only the presidency (between 1999 and 1903), but over 6,000 hectares of land. This platform was used to establish itself first, as a leading coffee producers, but subsequently diversified into finance (Banco del Comercio), electrical utilities, and sugar estate s (Paige 1997, p. 18). Their current main activity is production of sugar and derivatives.

The control that the coffee-elite acquired over banks later impacted on the development of business groups in many ways. An important hypothesis in the literature on diversified business groups, is that business groups form with a financial institution in their midst in 
order to overcome the limitations of weak financial markets. In Central America, the evolution of banks was closely associated with the development of the coffee trade. Banks were established across the region mainly owned by the coffee-elite and directed towards serving their interests, starting with the creation of the Banco Anglo Costarricense in 1864. The only bank originating in the other prosperous sector of the time, the banana export, was Banco Atlantida of Honduras (founded in 1913), owned by the Vaccaro Brothers, one of the three dominating banana producers in Honduras at the time. In all the other countries, banana production was owned by foreign companies and generated financial institutions in the United States rather than in Central America (Bulmer Thomas 1987).

The control over banks allowed the coffee elites to diversify into other agricultural and industrial activities when opportunities opened up. However, since they were often unwilling to fund other activities, this control also contributed initially to stifling industrial development by domestic entrepreneurs in the early 20 th century.

It was rather new immigrant groups that established themselves in industry and commerce, and often initially utilizing their own funds and savings. The diverse trading networks that were established in the United States and Europe through the coffee-trade attracted a number of immigrants. They often began import-export businesses, relying on existing connections in Europe and North America. Later, as they became knowledgeable of the coffee business, they invested in coffee-processing mills and subsequently in plantations, ensuring their position within the elite (Williams 1994, p. 182). For example, the De Sola (Homarca) and Cristiani groups from El Salvador both originate in European immigrants that first were established in commerce and later moved into coffee processing.

Also the few industrial establishments existing at the time - the textile industry in El Salvador and Quetzaltenango in Guatemala, the Guatemalan cement industry and two small iron 
foundries in El Salvador - were all established by European immigrants bringing their own funds, and often struggling hard initially to gain acceptance for policies favorable to industry in the states dominated by the coffee-elite (Dosal 2005). Among groups that trace their roots to the early industrial establishments we find for example, the Guatemalan Grupo Multiinversiones (Gutierrez/Bosch) and Cementos Progreso (Grupo Novella), both originating in industries established by European immigrants in the first half of the 20th century.

The other main group of immigrants of this time was Arabs, mostly from Palestine, but also some from Syria and Lebanon. The Arabs did not buy land since they initially did not see their residency in the region as permanent (Foroohar 2011). Therefore they mainly focused on commerce, services and in some cases industry. In spite of several intermarriages with elite families, they always stayed a somewhat separate elite, as is particularly well documented in the case of Honduras (Euraque 2009, 2012). As we will see in the following, the groups of Arab origin are currently among the principal business groups in the region, including Grupo Atala Faraj (Fischosa) from Honduras or Grupo Siman from El Salvador. They are also highly inter-linked among each other, but they are less integrated with the rest of the groups.

After the upheaval of the Great Depression and the Second World War, Central America experienced two new agro export booms. Between the late 1950s and 1975, the Central American countries experienced a significant increase in cotton production. This attracted new immigrants, but also gave an important investment opportunity for the old coffee elite. Cotton required larger investments but also gave quick returns. This meant that credit was of key importance, and members of the main cotton growing families frequently also became owners and managers of banks (Williams 1986, p. 44-48).

The opposite was true for sugar production; it required little initial investments, but was originally of modest scale and destined mostly to production of panela (a crude sugar 
processed in artisanal form) and fabrication of rum and other liquors (Fonseca 1996, p. 146). In 1929, sugar made up only between 1.3\% (in Guatemala) and 4.9\% (in El Salvador) of the export income of the sugar producing countries (that excluded Costa Rica) (Bulmer-Thomas, 1987, p.37). In the 1950s it went through a modernization process led by local groups such as Grupo Pellas-Lacayo in Nicaragua and supported by local banks, in the case of the Grupo Pellas-Lacayo, of Banic and Banamer. This led to increased milling capacity and efficiency that enabled the Central American producers to benefit from the market opportunities occurring in the United States after the Cuban revolution had led it to close the market for Cuban sugar. The result was a major sugar-boom in the 1960s (Bulmer-Thomas 1987, p. 1958-59). The mentioned Grupo Pellas as well as Guatemalan Grupo Pantaleon (Herrera family) are examples of groups whose fortunes were greatly expanded during this period and that later expanded into other sector.

The rise of prices of the principal agro-export products between 1945 and 1954 allowed the landholders to diversify into industry, a process that later flourished under the generous protection of the import substitution scheme of the Central American Common Market (CACM). From the late 1950s to the early 1970s a number of industrial enterprises were established, and by 1970 over 70 percent of industrial production was controlled by local companies. Many of these were artisanal, small companies, but also the agro-export elite entered into industry (Bulmer-Thomas 1987, p. 2190-95) often reinvesting the surplus from the agro-export, circulated through national banks owned by the same agro-export elite, although a separate industrial bourgeoisie also Most of it could be characterized as light industry: food and beverage, householdgoods, shoes and textiles. The only main exception were agricultural machinery and cement. This diversification gave rise to the first truly diversified business groups from Central America, for example Grupo Cressida (now Dinant) 
from Honduras led by Miguel Facussé of Palestine origin, that started to produce soaps and detergents on license from different MNCs, including Procter \& Gamble.

However, it was not only the protection of the CACM that provided business opportunities. A major additional source of diversification was governmentally sanctioned private monopolies in the production of basic goods and sometimes services. There were different reasons for their monopoly status: many sectors enjoyed high tariff protection, but in addition many industries enjoyed governmental price regulations such as the cement industry, they have been regulated by private associations that controlled prices and entry of new actors (as for example the sugar industry in Guatemala), exclusive governmental contracts (as for example in the pharmaceutical industry), or they emerged due to the exclusive support by the state to specific industries an later managed to keep their position due to high entry barriers. Of the sectors that have been highly monopolistic we find the production and distribution of beer, liquor, flour, rice, poultry, sugar, flour, rice, poultry, and cement, as well as the distribution of gasoline, and pharmaceuticals in addition to the governmentally owned services that generally were monopolies in most part of the world including electricity and telecommunication (Férnandez 2005, Tábora 2007, Romero 2006, Molina 2007).

\subsubsection{The lost decade and the economic transformation}

In much of Latin America the 1980s is named "the lost decade" due to the unraveling of the deb-crisis, and with that, the collapse of the development model that had characterized the region since the 1950s. However, for Central America, the 1980s were lost in economic terms for an additional reason, namely the conflicts ravaging Nicaragua, El Salvador and Guatemala with reverberations across the region. The combined effect of the reduction of agricultural production, the fiscal- and, for some countries, debt-crisis, and the end of the cold war that facilitated the peace-accords and the end to insurgencies and military dictatorships, was a 
transformation of the economic model. Yet, this transformation was crucially influenced by a set of economic reforms implemented across the region. Although there were very significant differences between the countries, one may sum up the reforms with the most significant implications for the DBGs under three major headlines: the modernization of the state and de-monopolization/privatization of public services, the support of a new development model and the liberalization of trade and opportunities for foreign investment. In sum, these reforms created a model that was more open to flows of capital and goods from outside the region as well as intra-regional trade and investments.

The reform process started at different points in the different countries and occurred in three principal ways: by the adoption of unilateral policy measures, some of which were included as conditionalities for different structural adjustment programs, bilaterally as part of international trade agreements and regionally, as part of the process of integration under the renewed new Central American integration scheme, the System of Central American Integration (SIECA) reviving the Central American Common Market (CACM) but in a context of parallel international liberalization (Chamorro and Nájera 1998).

The first country to adopt a structural adjustment program was Costa Rica. After having declared a unilateral debt moratorium in 1982, it signed the first structural adjustment loan with the International Monetary fund in 1985 (Sojo 1995). Honduras followed in 1988, and the rest of the countries in the 1990s. These programs were initially focused on macroeconomic stabilization, but the second phase of structural adjustment entered into significant details on the reform of the state, particularly downsizing of the public sector, privatization of public companies, and limitations on public investments. The reforms actually implemented where not only a result of the pressure from the international financial institutions, but equally from private sector associations and local think-tanks associated with 
it, often supported by the United States Agency for International Development (USAID) (Sojo 1995, Rosa 1993, Bull 2005). With the partial exception of Costa Rica, the reforms resulted in the opening of key public services such as telecommunications and electricity generation and distribution, to private investors. In the phase of what is often called the "third generation reforms", efforts were also made to strengthen the regulation to combat new and old monopolies. New institutions to regulate the newly privatized sectors were created across the region in the 1990s (Bull 2005). However, only Costa Rica and Panama had competition laws and regulatory institutions monitoring them until the mid-2000s, when El Salvador, Honduras and Nicaragua passed similar laws to those of Panama and Costa Rica (Rivera and Schatan 2008, Damtoft and Irizarry 2011). As of 2013, Guatemala still does not count on a competition law although different drafts have been debated for many years, the existence of competition laws was a requirement for the entering into an Association Agreement with the European Union. ${ }^{1}$

These reforms had the effect of first, opening new sectors for private investment, mainly electricity and telecommunication, but also in the financial sector in the cases where those had been nationalized (Kasahara 2012). In the telecommunication sector local groups entered mainly as junior-partners of transnational companies, portfolio investors or short-term investors, due to lack of access to technology and sufficient capital (Bull 2005), whereas the energy sector, on the other hand, has been a main new source of revenue for Central American groups. Grupo Terra (Freddy Nasser) from Honduras is an example of a group that owes its fortune to this process. Through the telecommunication company Megatel, Nasser acquired mobile licenses and company shares in the processes of telecommunication privatization in Honduras and Nicaragua. He later sold them to Mexican Grupo Carso (Carlos

\footnotetext{
${ }^{1}$ http://www.elperiodico.com.gt/es/20120830/economia/217191/. For a critical debate of the law-proposal discussed, see http://www.plazapublica.com.gt/content/una-ley-de-competencia-que-legitima-los-monopolios
} 
Slim), and used the revenue for investment in hydroelectric power-plants and a number of other sectors in Honduras and Guatemala.

One reason for the fiscal crisis was the reduction in agricultural production and/or prices that led to a reduction in the percentage of PIB accounted for by the primary products sector. Thus, a second major set of reforms were directed towards the support of non-traditional agricultural and industrial exports as well as tourism aimed to make up for the loss of revenue from agroexports and reduce its traditional vulnerability to the fluctuation in commodity-markets. This was done through the creation of free trade zones, tax-exemption schemes, facilitation of credits and labor reforms to enable access to the required cheap labor. The result was a transformation of the economic model and the facilitation of new lines of accumulation principally in the maquila and tourism sectors and also a few non-traditional agricultural goods (such as cardamom and pineapple) (Segovia 2004, Robles Rivera 2010).

The third major set of related reforms came in the trade and foreign investment policies. After the reinvigoration of SICA by 2012, 95.7 percent of the tariffs in the region were harmonized, and Central America had the highest percentage of intra-regional trade in Latin America (26 percent), meaning that it had returned to the level at which it was in the 1970s, after the dramatic reduction (to around 10 percent) experienced in the 1980s. At the same time, the trade with the rest of the world increased, first under preferential schemes such as the Caribbean Basin Initiative, and later in the framework of WTO and trade agreements with 17 countries or groups of countries. The by far most important of these agreements was the DRCAFTA signed with the United States - the most significant trading partner of Central America - and the Dominican Republic in 2003. DR-CAFTA encompasses all economic sectors and has a goal of full free-trade although at differentiated paces and with some minor exceptions. As is well known, it also grants full investor-protection and open competition on 
governmental procurements, protection of intellectual property rights among other areas included.

\section{$<$ Figure 1.1 in approx. here $>$}

As a result of the agreements, the region went from having a three digit foreign tariff on many goods until the 1980s, to an average external tariff rate of 6 percent in 2011, the lowest in Latin America and the Caribbean (CEPAL 2012). This contributed to a significant expansion also in extra-regional foreign trade (see figure 1.1). By 2011, Central America's total trade counted as the sum of exports and imports made up 82 percent of the region's GDP (CEPAL 2012). It is thus consider the region with the highest degree of trade-openness in Latin America.

The major DBG leaders were staunch supporters of the structural reforms as well as regional integration and the trade agreements, particularly DR-CAFTA, although there were differences in sector-priorities (Condo, Colborn and Rivera 2005, Bull 2012). However, it is clear that not all the reforms had the expected effects, and thus that it benefitted some groups more than others.

One of the main expectations of DR-CAFTA was that it would consolidate the region as a destiny for foreign direct investment (FD). However, the performance in terms of FDI attraction has varied significantly between countries and over time as shown in figure 1.2. There is an increase, but Panama and Costas Rica accounts for most of it, and some of the other major spikes can be explained by the sale of domestic enterprises to MNCs.

\section{$<$ Figure 1.2 in approx. here>}

Moreover, as shown in figure 1.1., although trade increased in total, and the Central American region consequently became relatively more open to trade than other countries of similar 
income levels, imports rather than exports are the main source of this trade openness, resulting in major trade deficiencies. While Nicaragua historically runs the highest trade deficit in the region (near 30\% of GDP in 2010), Honduras and El Salvador's trade deficits are also high (around 20\% of GDP in 2010) (World Bank 2012). Thus, while many Central American businesses were satisfied with having gained sustained access to the US market, among them the sugar growers and maquila producers, and the importers faced less obstacles in their business, many DBGs also met new challenges.

These were confronted through different strategies in which the DBGs have ben exploiting the opportunities involved in the new model, as well as defending themselves against the challenges it presented. These are the topic of this book.

\subsubsection{Economic growth, distribution and productivity in the new economic model}

The Central American economies have over the last decade performed markedly differently in terms of economic growth and technological upgrading. As shown in table 1.1 the six countries differ both regarding the size of the economies (Gross Domestic Product (GDP), economic growth and income levels, measured in GDP per capita.

The first thing to notice is the different size of the economies. Guatemala is the largest economy with a GDP five times larger than that of Nicaragua, the smallest economy in the isthmus. The second major difference is income levels per capita, with Panama on top with with 16856 USD in 2012, while Honduras and Nicaragua are among the poorest in the hemisphere with 1542 and 1267 USD per capita respectively. Also growth rates have differed significantly over the years. The decade between 2003 and 2013 was characterized by high growth in most of Latin America, with a steep slump in 2009 due to the financial crisis. The Central American sub-region has largely followed this trend. However, there are very 
significant differences between the different countries. While Panama has performed significantly better than average, and partly also Costa Rica, the rest of the countries have generally performed slightly worse. The last decade, El Salvador in particular has shown weak results and growth in Guatemala has also been mediocre, while the two poorest countries, Honduras and Nicaragua have had a volatile, but at times satisfactory growth.

\section{$<$ Table 1.1 in here>.}

When looking at the explanations for the varied growth results, one important factor is productivity. Studies of Total Factor Productivity (TFP) shows that Central America (with the exception of Panama) has lagged significantly behind the Latin American average over the last decade regarding this, and the worst performer, El Salvador, has seen a falling TFP (Fajnzylber, Guasch and López 2009). On rankings of competitiveness and business climate, the Central American countries are generally performing badly: on the World Bank Investment Climate Index (2011), the Central American countries rank from 84th place (El Salvador) to 141th (Honduras) out of 183 countries listed. In the Global Competitiveness Report from the World Economic Forum, the Central American countries again perform badly, on most indicators related to innovation and productivity growth (WEE 2011). As an example, total spending on R\&D did not exceed 0.06 percent of GDP in any of the Central American countries, whereas the average for Latin America was 0.54 percent (Lederman 2007). A number of other prerequisites for industrial upgrading are also found to be missing. Among them is good quality infrastructure and logistics. The Central American countries are found to be deficient on most accounts ranging from electricity supply and mobile telephone subscriptions to quality of roads and ports (WEE 2011).

A main explanation for the above in the $\mathrm{VoC}$ literature is the existence of atomistic labor markets and low levels of skills and training. Most workers have fluid, short-term links to 
firms, and they have few and weak links to other workers through labor unions. All of these conditions are even more accentuated in Central America than the rest of Latin America. While the unionization rate is 45 percent on average in CMEs, it is 28 in LMEs and 15 percent in Latin America (Schneider and Karscher 2010). However, it is only 8 percent on average for Central America, and there are significant differences across the countries. Only 2 percent of the labor stock is organized in Guatemala, the corresponding number is 7 percent in El Salvador, 8 in Honduras, 9 in Costa Rica, 12 in Nicaragua and 13 in Panama. ${ }^{2}$ Furthermore, in some Central American countries, labor markets are characterized by extreme levels of informality. In Central America the percentage of the population (outside agriculture) that is employed in the informal sector varies between 70.7 percent in Honduras, and 65.7 percent in El Salvador to 39.3 percent in Panama and 33.6 percent in Costa Rica (OIT, 2012, no data for Guatemala and Nicaragua).

High levels of informality labor is both a sign of atomization itself, and a factor contributing to low levels of on-the-job training and thus low levels of skill development. This adds to the already low levels of education and skills. While education levels have increased significantly over the last years, and in particular, the extension of basic education, the levels vary across the countries. In Guatemala people above 24 years of age have an average of 4.1 years of education, while the corresponding figure for the other countries are: 5.8 (Nicaragua), 6.5 (Honduras), 7.5 (El Salvador), 8.4 (Costa Rica) and 9.4 (Panama) (UNDP 2013). Compared to other Latin American countries, only Costa Rica and Panama reaches the average, whereas the countries of "high human development" reaches between 12 and 13 years of schooling. ${ }^{3}$

\footnotetext{
${ }^{2}$ See chapter 5 in this volume. For further information see also http://white.oit.org.pe/spanish/260ameri/oitreg/activid/proyectos/actrav/proyectos/proyecto_ssos/act_regio nales/mexico_nov2010/documentos/3erdia_cancun1.pdf

${ }^{3}$ http://hdrstats.undp.org/en/indicators/103006.html
} 
The atomistic labor relations and low levels of skills and training complement the dominance of MNCs and business groups, since both MNCs and business groups have relatively low demand for skilled labor and weak incentives to press for widespread investment in education and training and the absence of a large pool of skilled workers discouraged domestic firms from investing in upgrading their production or in other higher technology sectors, and instead encouraged domestic firms to target lower technology investments where appropriate skills were abundant in the labor market (Schenider 2013, p. 26).

\subsection{Understanding business group strategies in open and changing institutional contexts}

The debate about the political economy of Central America has long been quite polarized. In the process of economic reforms from the late 1980s, some saw the state as the main culprit of stagnant growth and low productivity. With its allegedly bloated state apparatuses, myriad of regulation and red-tape, and inefficient bureaucracies, it was viewed as stifling business initiatives, out-crowding private investments, and contributing to business-hostile macroeconomic volatility. As elsewhere, the solution was to be found in unleashing business initiatives by reducing and reforming the state presence. However, while surveys attempting to unveil the views of business on the main obstacles to their growth flourished, often conducted by private sector think-tanks, very little research was done on the ownership structure of the companies, their main strategies and investments: the focus was on the state and how it should be reformed.

Against this, it was argued that the problem was not the magnitude of the state or its presence in the economy, but rather that it had always favored a small elite of capitalists that were preoccupied with serving their own interest, not that of the countries as a whole. Yet, having structural rather than institutional focus, their main concern was to reveal the concentration of 
capital in the hands of a ruling class and how it influenced state policies, and not how they organized and reorganized their enterprises and the implications that had for the economy as such.

This book is an attempt to carve out a different position by focusing on the business groups, their internal organization, how they try to both influence and adapt to a volatile economic environment and rapidly changing institutional context. As such, we not only attempt to contribute to debates about Central American development, but also to the international literature on why DBGs emerge and thrive, and whether they represent important determinants of productivity and growth in developing countries. Specifically, how do DBGs respond to the process of institutional transition and market development that characterize many developing economies worldwide? Are they progressively shrinking and weakening their dominant market position and political influence - or, by contrast, are they adapting to a new market-based competition and finding new strategies and market niches to support their market dominance?

Our findings point to that the DBGs are not in the process of being subsumed by the MNCs, nor do the majority thrive in the global economy. Some groups are struggling hard to compete with MNCs and they diversify as a means of defending themselves against MNC competition, many have refocused their activity to sectors wherein there are still possibilities to create defacto monopolies or oligopolies or they have particular competitive advantages as local groups, and many have established links with MNCs in order to access technology, new products to distribute or brands to produce. Many have cross-border investments, but only a few are moving towards being successful MNCs themselves. 
The questions are: what can explain the different strategies? What are the implications for the development of the region? Can we see a new form of capitalism emerging in Central America as a result of the increasing penetration of MNCs and expansion of the DBGs abroad?

In order to answer that, two concepts from the Varieties of Capitalism literature have proven particularly useful: hierarchies and networks. The concept 'hierarchical capitalism' is launched by Schneider to depict the Latin American capitalism where hierarchical relations not only govern the internal structure of the two dominant economic organizational forms the diversified business group and the MNC - but also relations among firms both within sectors where large firms dominate economically (oligopoly) and in associations as well as across sectors and borders in that business groups and MNCs buy and control firms that would be independent in other varieties. As such, 'hierarchies replace relations that in other varieties would be mediated by markets, networks, or coordination.' (Schneider 2013, p. 40). In Central America, hierarchical relations are evident in the daily operation of the groups, and the command that the group leaders have over an array of companies in different sectors provides a crucial resource in their survival and growth. However, the hierarchies also characterize the MNC structure and their introduction to Central America has shifted the kind of hierarchies that the companies relate to. This is evident in the access to technology, but also in some countries access to finance. Moreover, in the current process of regionalization new hierarchies are formed when groups from one country buy a number of independent companies in the neighboring countries. ${ }^{4}$

However, although hierarchies are important, it is impossible to understand of the DBGs without also taking into account how they function as networks and within networks. While the DBGs characterized by being horizontal networks bound together by a set of social norms

\footnotetext{
${ }^{4}$ See for example the presentation of Grupo Multi-Inversiones in chapter 4
} 
and economic self-interest between conceptually equivalent units (Hamilton and Feenstra 1995) are quite rare in Central America, networks between DBGs and other actors is often what allows the companies to compete even with companies with superior technology or access to finance. With the transnationalization of the economy, due to the sale of a number of companies in which the DBGs held majority, network coordination has become a more predominant as the group owners have entered into various companies as minority shareholders.

Our argument is that while hierarchies characterize the relationship between DBGs and MNCs, as well as between the large DBGs and smaller groups and independent companies, networks characterize the relations between several of the large DBGs and important political institutions. Networks are strengthened when DBGs pool resources in order to make investments in the magnitude needed to compete with MNCs; networks are also needed when red-tape is to be overcome, governmental bids are to be won, or licenses acquired. These networks are distinct from the coordination found in the CMEs because they are based on a set of informal institutions that are stable and long term and not up for negotiation. The long term nature of hierarchies and networks stand in contrast to the atomistic relationship with labor and the relative isolation from local communities, and the privileged position in such networks give the DBGs a permanent role in the economies.

Further, because of the structural and long-standing characteristics of the networks in which DBGs are embedded, groups are often better able than independent companies to coordinate and get access to tangible and intangible resources, exploit external economic and policy opportunities, upgrade their managerial and technological capabilities, and strengthen their market dominance even in the presence of a rapidly changing institutional context. The interlinks and complementarities between groups' resources, capabilities and strategies, on the 
one hand, and the institutional characteristics of the environment in which they operate, on the other, represents a major avenue to explain the resilience and continued superiority that DBGs are proving to have in developing economies worldwide. We will explore this research avenue in the next chapters.

\subsection{Research strategies, methods and the plan for the book}

This book is based on a multidisciplinary approach and has sought to combine a number of different methods for data-collection and analysis. We have made use of six principal sources of data. First, where existing we have used public registries. Those are available mainly in the Company register in Panama. There are also some data (on company ownership and composition of boards) in the Mercantile Register in the National Center for Registries (CNR) in El Salvador. Second, we have used company web-sites and websites of business associations. Particularly export associations maintain useful websites with overviews over companies associated, but also some other organizations have such information available. Third, we have used newspapers and business magazines particularly to gain information about mergers and acquisitions or the investment in new projects. Newspapers and magazines have also been a valuable source about the political strategies of business groups. Fourth, we have undertaken a survey among both group affiliated and stand-alone firms in the region on their internationalization strategies. However, in spite of having sent hundreds of requests of participating and spent considerable resources on follow-up calls, we received a too low number of responses to be able to lend much importance to this survey. The results are referred to in chapter 6 , but interpreted with care and cross-checked with other data. Fifth, we have conducted a number of interviews with business group leaders and with experts knowledgeable about them. This has been used to correct the material we had already collected in order to get a better idea of their strategies, the companies belonging to the groups 
and importantly, on the evolution of their groups over time. Sixth, and finally, we have complemented our own data with data from the World Bank Enterprise Survey 2010-2011.

With the exception of the surveys (our own and that of the World Bank), the data has been used to compose a database (discussed further in chapter 2) that has been the basis for a substantial part of the analysis. This analysis has been done at three different levels: the regional (Central American) level, the national level, and the level of individual DBGs. As a result, Central America is sometimes treated as a unit, when we talk about Central American groups, and sometimes it is treated as the universe and the six different countries are the units that are compared in the analysis. Moreover, we have attempted to combine the study of the state of affairs today with process analysis, tracing developments over time to investigate how institutional and policy changes coevolve with groups' strategies in a long run perspective

We have also used a variety of techniques and methodologies for analysis. Chapters 5 and 6 uses quantitative techniques to reach conclusions about the export performance and innovativeness of group related firms compared to stand-alone firms, and to analyze how that performance can be explained by pointing to institutional variables. In this case, different institutions are given values as 'strong' or 'weak'. In the following chapters, we 'unpack' several of these institutions and describe them in more qualitative terms as well as attempt to uncover aspects of their co-evolution with the DBG strategies. Thus, we move both from a quantitative to a qualitative approach, and from an 'outside' view attempting to sustain causal mechanisms, to an 'inside' view aimed at interpreting institutions and sequences of events within their national and historical context. In other words: we move from an explanatory to an interpreting mode of analysis and from asking questions of 'why?' to also including an investigation of the 'how?' and the underlying explanatory process. 
Applying such a multitude of methods and techniques has its clear advantages but also disadvantages. We hope to be able to give a thorough picture of the Central American DBGs, the transformations they are currently undergoing and how that is affected by the institutional context, while at the same time affecting it. However, the book does not intend to provide a parsimonious model for institution-DBG interaction or a clear prediction of where the Central American DBGs are headed. Rather, it attempts to provide a coherent framework to interpret the complexity of the realities of these small, but very different, neighboring countries, but without losing sight of the differences between groups, economies, institutions and policies.

The rest of this book is outlined as follows. The next chapter provides an analytical framework for the analysis of the strategies of the Central American DBGs. It draws on the vast comparative literature on the emergence and impact of the DBGs, and on the more specific literature on DBGs and globalization. It further builds on the institutional literature on Varieties of Capitalism (VoC) and DBGs.

Chapter three provides a general overview over the changes that the DBGs have undergone in Central America, along three dimensions: shift in sector focus (differentiation), establishment of relations with MNCs, and expansion abroad. This regional analysis is complemented by an analysis of national trajectories that uses the same variables but attempts to place the national differences in a historical and institutional context.

Chapter four intends to give a 'face' to the DBGs by studying the formation, expansion, sector shifts, alliance formation and political connections of six of the most emblematic business groups in the region: Grupo Multiinversiones (Gutierrez-Bosch) from Guatemala, Grupo 
Poma from El Salvador, Grupo Continental (Rosenthal) from Honduras, Grupo Pellas from Nicaragua, Grupo Motta from Panama and Grupo Montecristo from Costa Rica.

Chapter 5 focuses on one important strategy of internationalization, export sales, that has so far received only limited attention in the literature. The chapter compares the export performance of the business group affiliated firms to the non-affiliated or "standalone" firms, seeking to explain whether being affiliated with a DBG has positive or negative effect on Central American companies' export sales.

Chapter 6 shifts the focus to the innovation activities of DBGs, and it seeks to scrutinize empirically whether groups' innovative capability and investments increase or decrease when a national economy undertakes a process of institutional change, liberalization and market development.

While these two chapters focus on different development impacts of DBG dominance, chapter 7 and 8 turn to the explanations for differences across countries. In chapter such explanations are sought in differences in institutions regulating the financial sector and how they have evolved over time. This explains the differences in the weight that financial companies have in the groups across the countries, but can also shed light on their general sector preferences.

Chapter 8 turns to the political strategies of the DBGs and attempts to understand how those in part are shaped by their home countries' political institutions and in part shape those. Their strategies are studied across four presidential periods, but a particular weight is put on those periods in which there have been presidents in power that have challenged the core interests of the DBGs. 
In sum, the book presents a view of Central American DBGs and the institutions of their home countries as knit together in a long-term co-evolutionary process: groups' strategies are largely shaped by domestic institutions, but their actions are in turn of deep consequence for the same institutions and the development trajectories that they follow over time to adjust to the process of market development and institutional change. The following chapter will elaborate that perspective in full. 